The Soviet Union and the Origins of the Second World War 


\section{The Soviet Union and the Origins of the Second World War}

Russo-German Relations and the Road to War, 1933-1941

Geoffrey Roberts

Macmillan Education New York 
ISBN 978-0-333-55697-9

ISBN 978-1-349-24124-8 (eBook)

DOI 10.1007/978-1-349-24124-8

THE SOVIET UNION AND THE ORIGINS OF THE SECOND WORLD WAR

Copyright (C) 1995 by Geoffrey Roberts

Softcover reprint of the hardcover 1st edition 1995

All rights reserved. No part of this book may be used or reproduced in any manner whatsoever without written permission except in the case of brief quotations embodied in critical articles or reviews.

For information, address:

St. Martin's Press, Scholarly and Reference Division, 175 Fifth Avenue, New York, N.Y. 10010

First published in the United States of America in 1995

ISBN 978-0-312-12603-2 (cloth)

ISBN 978-0-312-13259-0 (pbk.)

Library of Congress Cataloging-in-Publication Data

Roberts, Geoffrey K.

The Soviet Union and the origins of the Second World War : Russo

-German relations and the road to war / Geoffrey Roberts.

p. $\mathrm{cm}$.

Includes bibliographical references and index.

ISBN 978-0-312-12603-2 (cloth) — ISBN 978-0-312-13259-0 (pbk.)

1. World War, 1939-1945-Causes. 2. Russia-Relations-Germany.

3. Germany-Relations-Russia. I. Title.

D741.R53 1995

327.47043'09'043—dc20 
For Mother 


\section{Contents}

Preface

ix

1 Introduction: Conflicting Views on the USSR and the Origins of the Second World War

2 From Co-operation to Confrontation: The End of Rapallo and the Turn to Collective Security, 1933-1935

3 Confrontation versus Compromise: Dilemmas of Coexistence with Nazi Germany, 1935-1937

4 To the Brink of War: The Czechoslovakian Crisis of 1938

5 From Confrontation to Conciliation: Origins of the Nazi-Soviet Pact, 1938-1939 62

6 The Nazi-Soviet Pact and the Partition of Poland 92

7 Expansion and Coexistence, 1939-1940 103

8 Crisis and Conflict, 1940-1941 122

9 Stalin and the Road to War, April-June 1941

10 Conclusion $\quad 147$

Notes and References 151

$\begin{array}{lr}\text { Select Bibliography } & 178\end{array}$

$\begin{array}{ll}\text { Appendix } & 186\end{array}$

$\begin{array}{ll}\text { Index } & 188\end{array}$ 


\section{Preface}

This book about the USSR and the Origins of the Second World War concentrates on the story of Soviet-German relations in the period from the rise of Hitler to the launch of Operation Barbarossa in June 1941. There is, of course, much more to the Soviet role in the events leading to war than just the USSR's relationship with Germany. Relations with Great Britain, France and other countries, the Soviet response to the threat from Japan in the Far East, the role of the Communist International - all would need to figure in a comprehensive treatment of the subject. However, the Russo-German relationship is, arguably, the central part of the story. It is certainly the most controversial, and the subject on which recent releases from the Russian archives have been most revealing. In this connection readers should note that although this book is largely based on Soviet archival sources I have not had the benefit of direct access to the archives, which remain effectively closed to western researchers. No doubt when the Russian archives are finally opened up many of the interpretations and conclusions in this book will have to be revised. However, I am confident, given the wide range of published archival material now available, that the main lines of the story told here will be revalidated.

Thanks are due to John Erickson and Philip Windsor for valuable comments on a PhD thesis on which this book is in part based. Teddy Uldricks' supportive role as a kindred spirit in a fiercely contested field of research has been of inestimable value. Thanks to Brian Girvin, my colleague in the UCC History Department, for his intellectual companionship over the past two years. As ever, the most thanks to Celia Weston, my intellectual, emotional and practical partner in this and all my other projects.

The present book draws substantially on my previously published work: 'The Soviet Decision for a Pact with Nazi Germany', Soviet Studies (January 1992); 'The Fall of Litvinov: A Revisionist 
View', Journal of Contemporary History (October 1992); 'Infamous Encounter? The Merekalov-Weizsäcker Meeting of 17 April 1939', Historical Journal (December 1992); 'Military Disaster as a Function of Rational Political Calculation: Stalin and 22 June 1941', Diplomacy and Statecraft (July 1993); 'A Soviet Bid for Coexistence with Nazi Germany, 1935-1937: The Kandelaki Affair', International History Review (August 1994); and The Unholy Alliance: Stalin's Pact with Hitler (London, 1989).

Finally, I would like to thank Geoffrey Warner, who commissioned the book, and to acknowledge the inspiration I derived from the publisher's anonymous referee who described the manuscript as 'highly entertaining and instructive ... an original account, packed with controversial theses and extravagant with disputatious as well as disputable asides'. I hope that other readers find the book equally interesting and controversial. Needless to say, I accept full and sole responsibility for its contents. 